\title{
BJMIR
}

British Journal of Medical and Health Research

Journal home page: www.bjmhr.com

\section{Benzoic Acid Induced Pathological Alterations In Hepatic and Intestinal Cells of Rattus norvegicus}

\section{Chavan MM*, Sathe JS, Kamble GP, Surve VB, Kamble NA. Department of Zoology, Shivaji University, Kolhapur.}

\section{ABSTRACT}

Excess oral administration of Benzoic acid has been reported to have adverse effects on various organs. For present study, we aimed to assess putative hepatic and intestinal alterations if, repeatedly exposed to induced doses of benzoic acid against selected vertebrate animal model. Wistar rats were divided into five experimental groups as control, 30 days, 45 days, 60 days and 75 days respectively. Investigation was carried by were dividing animals into 5 groups. Group $1^{\text {st }}$ is control group, while remaining 4 groups were treated with calculated dose of Benzoic acid $(1.8 \mathrm{mg} / \mathrm{ml} /$ day or $45 \mathrm{mg} / 25 \mathrm{ml} /$ day $)$. Animals from all groups were sacrificed according to CPCSEA guideline. Understanding the paramount importance of liver and intestine the metabolism and as these organs are especially susceptible to toxicological damage. These organs were selected for histopathological investigation. Pathological investigations were interpreted for dependent biomechanics and behavioral changes in the experimental model Rattus norvegicus.

Keywords: Benzoic acid, Toxicity, Intestinal cells, Hepatic cells, Rattus norvegicus. 


\section{INTRODUCTION}

Benzoate are derived from Benzoic acid and are more commonly used as food preservatives than the acid and represents increased therapeutic and protective profile, (IPCS, 1993; WHO, 1996 and 1999; BMA, 1998) ${ }^{1-4}$. Benzoic acid as food additives improves flavor, taste, colour, texture, and food value (Kristie Leong, 2009; Center for Drug Evaluation and Research, 2017 and U.S. Food and Drug Administration, 2018). Olmo et al., (2015) $)^{5-8}$ reported benzoic acid and its derivatives as naturally occurring compounds in foods and as additives. Mroz et al., $(2000)^{9}$, documented biochemical effects of calcium benzoate mixed food stuff and related it to dietary buffering capacity, apparent digestibility, retention of nutrients and manure characteristics in intestinal cells and associated glands of experimental model as swine. Kristie Leong, (2009) ${ }^{19}$, reported that in some cases Sodium Benzoate through its biochemical derivatives functions as unhealthy food preservative causing adverse effect on morphological features vital cells. However, reports of adverse reactions, intoxications and fatalities have been reported by number of scientists.

Documentation pertaining to the molecular, biochemical, and histological alterations underlying their toxicological potential found missing. Srour, (1989) ${ }^{10}$ documented that, Benzoic acid may interfere the biochemical reactions by forming its intermediates and derivatives leading to cause cellular stress. Plitzner et. al., (2006) ${ }^{11}$ also observed similar kind of biological disturbances because of induced dose of benzoic acid on growth performance and metabolism alterations in fattening pigs. Cong et. al., $(2001)^{12}$, biochemically assessed absorption of benzoic acid in segmental regions of the vascular perfused rat small intestine preparation and documented the bioconcentration of induced molecule in the intestinal cells. Birch et. al.,(1989) ${ }^{13}$ documented total analysis and screening of chemicals for anaerobic biodegradability against the accumulation of animal body. Bindslev-Jensen, (1998) ${ }^{14}$ reported allergenic chemicals and their role in the development of food allergy which cause metabolic disturbances. As per toxicological study, excess concentration of benzoic acid can irritate the eyes, skin, lungs and digestive tract (Nair, B., 2001) ${ }^{15}$ Benzene exposure to large amount of the chemical can cause headache, dizziness, vomiting, muscle tremors, a rapid or irregular heartbeat, drowsiness and loss of consciousness. Similarly, RCC Notox, (1988b) ${ }^{16}$ and Monsanto Co., (1983) ${ }^{17}$ also reported photo interruptions and visual irritation/corrosion against benzoic acid in the rabbit.

Mroz et. al., (2000) ${ }^{18}$ find out effects of calcium benzoate in diets with or without organic acids on dietary buffering capacity, apparent digestibility, retention of nutrients and manure characteristics in swine. There are different types of effect of benzoic acid and combination of benzoic with citric acid as food additives on the excretory function of experimental rats. (Abd- 
AiGadir et. al., 2009) ${ }^{20}$. Bhelonde and Ghosh, (2004) ${ }^{21}$ investigated effect of subchronic fenpropathrin toxicity on feed consumption and body weight gain in experimental rats. Priya et. al., $(2008)^{22}$, reported hypoglycemia, hypercholesterolemia and hypoproteinemia in rats treated with sodium benzoate orally. Hirose et. al., $(2010)^{23}$ reported epithelial cell injury and oxidative stress induce calcium crystal formation in nephrocytes of mouse. Kubota and Ishizaki, (1991) ${ }^{24}$ critically investigated dose-dependent pharmacokinetics of benzoic acid after oral administration of sodium benzoate in humans and reported its pathological impact with irregular biomolecules. Zhu et. al., (2018) ${ }^{25}$ observed induced effects of melatonin as chemical compound on intestinal histomorphology with oxidative stress in colitis mice. Weichselbaum and Klein, $(2018)^{26}$ investigated intestinal epithelial damage against induction of excess chemical and its impact on the absorption of dietary substances in animals.

Cakıroglu et. al., (2016) ${ }^{27}$ reported biochemical stress formed occurred in vital organ like hepatic cells in the experimental animals. Diao, $(2013)^{28}$ reported effects of Benzoic Acid on Growth performance and gut health along with digestive deformities in Piglets. Polonen et. al., (1998) ${ }^{29}$, biochemically assessed different combinations of formic, propionic and benzoic acids in slaughter offal preservation for feeding to fur animals and reported nutritional depletion and physiological changes in the exposed animals. Windisch et. al., (2001) $)^{31}$ observed major effect of potassium diformate in combination with different amounts and sources of excessive dietary copper on productivity and bioenergetics of experimental weaning piglets. Taking account of available literatures and documentation, study was designed to investigate the effect of Benzoic acid on the structure of liver and intestine of rat providing pathological symptoms of hepatic cells and intestinal tissue in experimental model as Rattus norvegicus.

\section{MATERIALS AND METHOD}

\section{Animal Under study:}

Present investigation was carried out by using worldwide accepted vertebrate experimental animal model Rattus norvegicus. By applying standard protocol, animals were breed and reared in animal house in Department of Zoology, Shivaji University, Kolhapur (1825/PO/EReBi/S/15/CPCSEA). Wistar rats (Rattus norvegicus), aged 5 weeks and weighing 150-170 gms. were obtained from the animal house, theywere provided with proper space and kept in separate cages. All animals were taken care in accordance with the guidelines and as per the standard protocols recommended for handling of laboratory animals. Experimental animals were exposed to 12-hour light and 12-hour dark photoperiod. Mean room temperature was maintained in range between $70^{\circ} \mathrm{F}$ to $72{ }^{\circ} \mathrm{F}\left(21.9^{\circ} \mathrm{C}\right.$ to $\left.22.4^{\circ} \mathrm{C}\right)$ with maintaining mean daily relative humidity ranged from $37 \%$ to $48 \%$ throughout study period. Animals were carefully provided with recommended sufficient food in the form of pellets prepared by Pranav 
agro chemicals Industries, Pune. Reverse Osmosis (RO) water was provided with calibrated bottles for determination of accuracy in the induced dose calculations against experimental animal.

\section{Selection of toxicant:}

Andersen, $(2001)^{32}$, in his final report on the safety assessment of Benzyl Alcohol, Benzoic Acid, and Sodium Benzoate reported about biochemical properties of, powder form of Benzoic acid (solid, white crystalline substance, chemically classified as an aromatic carboxylic acid, preservatives. Verhoeckx et. al., (2015) ${ }^{33}$ documented Impact of Food Bioactives on biological mechanism of health and behavioural related problems of animals including human. biochemically benzoic acid starts to sublime at $100^{\circ} \mathrm{C}$, with a melting point of $122^{\circ} \mathrm{C}$ and a boiling point of $249^{\circ} \mathrm{C}$. It has solubility in water low $\left(2.9 \mathrm{gm} / \mathrm{lit}\right.$ at $\left.20^{\circ} \mathrm{C}\right)$, and dissociation constant at $25^{\circ} \mathrm{C}=6.335 \times 10-5$. It has an octanol /water partition coefficient of 1.9. Its vapour pressure at $20^{\circ} \mathrm{C}$ ranges from 0.11 to $0.53 \mathrm{~Pa}$, relative density of the vapour /air-mixture at $20^{\circ} \mathrm{C}$ $($ air $=1): 1$. With the above organic capacities the powder form of benzoic acid was used against experimental animal to assess its toxicity impact.

\section{Preparation of induction dose and experimental design:}

For experimental study, benzoic acid was used as an intoxicant. The calculated dose was 2700 $\mathrm{mg} / 1500 \mathrm{ml}$ water for $300 \mathrm{gms}$. body weight of rat.

$\mathrm{LD}_{50}=$ Oral $-2700 \mathrm{mg} 300$ gms. of rat 2.700 gms. $/ 1.5$ lit $=2700 \mathrm{mg} \mathrm{X}$ ?

So, $1 \mathrm{ml}=1.8 \mathrm{mg}$. $/ \mathrm{ml}$.

Now, $1 \mathrm{mg}$ in 1 lit=1000 ppm, $2 \mathrm{mg}$ in 1 lit=2000 ppm

$1.8 \mathrm{mg}$ in $1 \mathrm{lit}=1800 \mathrm{mg} / \mathrm{lit}$. Hence, $1.8 \mathrm{mg} \mathrm{X} 1000 \mathrm{ml}=1800 \mathrm{mg} / \mathrm{lit}$.

So, for $1500 \mathrm{ml}=$ ? ; $1.8 \mathrm{mg} \mathrm{X} 1500 \mathrm{ml}=2700 \mathrm{mg}$.

For induced toxicological study, stock solution of $2700 \mathrm{mg}$ powder of benzoic acid was thoroughly dissolved in $1500 \mathrm{ml}$ distilled water. Among rodents, related to acute oral toxicity of benzoic acid was calculated as oral $\mathrm{LD}_{50}$ values of $>1940 \mathrm{mg} / \mathrm{kg}$ body weight, reported by, Wibbertmann et. al., $(2005)^{34}$.

After maturity of 30 adult's experimental animal Rattus norvegicus were grouped in 5 groups, first set as control group having 6 animals. For second set total 24 animals were kept as experimental animal divided as 1,2, 3 and 4 groups respectively. Control animals were feed and reared with normal diet and water. While experimental animals were intoxicated with calculated and predetermined dose of benzoic acid for period of 30 days, 45 days, 60 days and 75 days respectively. All the procedure was repeated thrice for accuracy. Tabular presentation of experimental design with dose is as follows 


\begin{tabular}{llllll}
\hline Group & Control & $\begin{array}{l}\text { Expt. Group } \\
\text { 1- 30 days }\end{array}$ & $\begin{array}{l}\text { Expt. Group } \\
\text { 2- 45days }\end{array}$ & $\begin{array}{l}\text { Expt. Group } \\
\text { 3- 60days }\end{array}$ & $\begin{array}{l}\text { Expt. Group } \\
\text { 4- 75days }\end{array}$ \\
\hline $\begin{array}{l}\text { Number of } \\
\text { animals }\end{array}$ & 06 & 06 & 06 & 06 & 06 \\
$\begin{array}{l}\text { Concentration } \\
\text { of dose }\end{array}$ & - & $45 \mathrm{mg} / 25 \mathrm{ml} /$ day & $45 \mathrm{mg} / 25 \mathrm{ml} /$ day & $45 \mathrm{mg} / 25 \mathrm{ml} /$ day & $45 \mathrm{mg} / 25 \mathrm{ml} /$ day \\
\hline
\end{tabular}

\section{Selection of organ:}

After completion of oral administration for respective doses, all experimental animals were anaesthetized and scarified for interested biological tissues, the liver and intestine. By applying standard micro technique, tissues were excised and fixed in $10 \%$ formalin, followed by dehydration in ascending grades using ethyl alcohol grades. Finally tissues were cleared in xylene, embedded in molten paraplastat $56^{\circ} \mathrm{C}$. Sections were cut at $4-5 \mu$ on rotator microtome. Selected paraffin sections were stained with Haematoxylin and Eosin (Drury and Wallington, $1980)^{30}$. As per experimental design histopathological slides were observed under Inverted Phase Contrast Microscope (LYNX) for better toxicological analysis and compilation of results. (Plate No. 1 Fig. a, b. c, d, e and f).

\section{Statistical analysis:}

Statistical analysis was carried out by applying statistical method as mean (central tendency) with soft pad device of computer (Excel.). Gad and Rousseaux, $(2002)^{35}$ documented different ways for correct applications of statistics as an aid in study interpretation of toxicological data preparations in their Handbook of Toxicological Pathology. Obtained result were interpreted for toxicity assessment of benzoic acid against Rattus norvegicus.

\section{RESULTS AND DISCUSSION:}

To run the normal function of the animal, body gut associated with digestive glands proved as highly proliferative and secretary organs, which plays vital role in growth and health of the whole body (Turner, 2009) ${ }^{36}$. Intestinal cells are responsible for complete digestion and absorption of the food content consumed by animals. Associate to these organs, liver as largest gland in the body concerned with extreme metabolic functions, also carry an important role in the detoxification and storage metabolic contents. Graham and Lake, $(2008)^{37}$ studied induction of drug and its effect on different metabolism with its toxicological relevance and documented that, excess concentration of any drug can cause biological disturbances on the experimental animals. We found that, as per the dose we induced depending upon exposure weight of all animals were found reduced and has indicated internal intestinal and hepatic damage. The dose induced and rate of bio-concentration of benzoic acid in the selected found significantly proportional to cause damage against vital cells. Rate of consumption and bioaccumulation with its toxicity effect for 25 days, 50 days to 75 days in experimental animal Rattus norvegicus -The total consumption of dose of benzoic acid during experimental was $605 \mathrm{ml}(1089 \mathrm{mg})$, 
$906 \mathrm{ml}$ (1633.5 mg), $1314 \mathrm{ml}(2366.1 \mathrm{mg}), 1636 \mathrm{ml}$ (2944.8 mg) during period of exposure from 30 days, 45 days, 60 days, 75 days respectively (Graph 1). The concentration of benzoic acid consumed by rat increase in days of exposure period i.e. $30<45<60<75$ days.

Table 1: Benzoic acid (Dose) consumed by the Rattus norvegicus in mg

\begin{tabular}{lllll}
\hline Sr. No. & 30 Days & 45 Days & 60 Days & 75 Days \\
\hline 1 & 84.6 & 43.2 & 189.9 & 201.6 \\
2 & 203.4 & 185.4 & 189 & 185.4 \\
3 & 217.8 & 211.5 & 198 & 180 \\
4 & 174.6 & 203.4 & 207 & 199.8 \\
5 & 201.6 & 192.6 & 189 & 187.2 \\
6 & 207 & 205.2 & 198 & 194.4 \\
7 & NA & 189 & 199.8 & 189 \\
8 & NA & 207 & 196.2 & 196.2 \\
9 & NA & 196.2 & 208.8 & 194.4 \\
10 & NA & NA & 198 & 192.6 \\
11 & NA & NA & 201.6 & 199.8 \\
12 & NA & NA & 190.8 & 189 \\
13 & NA & NA & NA & 217.8 \\
14 & NA & NA & NA & 223.2 \\
15 & NA & NA & NA & 194.4 \\
& 1089 & 1637.5 & 2366.1 & 2944.8 \\
\hline
\end{tabular}

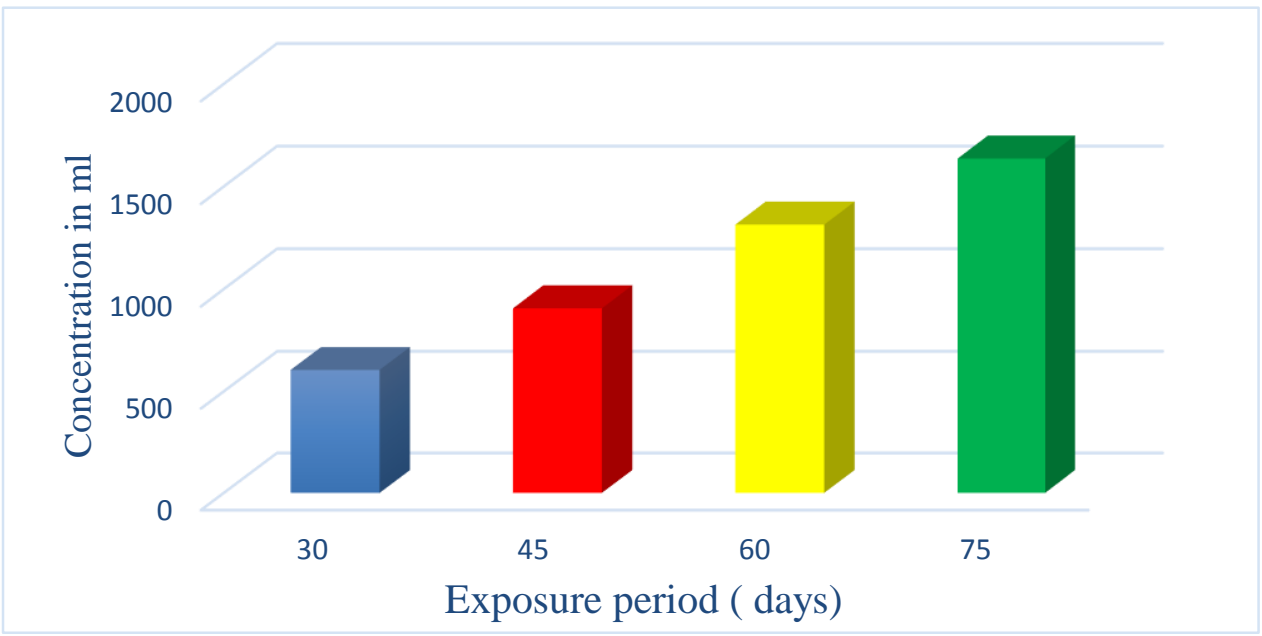

Graph 1: Benzoic acid (dose in $\mathrm{ml}$ ) consumed by Rattus norvegicus during entire induction period in days.

Goodman and Ishak, $(2006)^{38}$ observed pathological indications of hepatobiliary system while investigating cytopathology and biological changes of rat. Hailey et. al., (2005) ${ }^{39}$ reported classification of proliferative hepatocellular lesions in Harlan Sprague-Dawley rats after chronically exposed to Dioxin-like compounds and showed mild pathological changes in the hepatocytes of animals. By considering the induction mechanism and pathological symptoms of benzoic acid against some experimental animals, we assessed normal and pathological changes in selected organs of our animal model as Rattus norvegicus.

Histology of the liver and intestine: 
Among vertebrates, rat as best experimental model, when we observed cellular arrangement of hepatic and intestinal part we found that, in the control animal histomorphology of hepatic cells has preserved with its normal shape and size. In control animals, liver section by its microscopic architecture composed of huge number of hexagonal lobules and hepatic acini. Under sectional view, lobules were found concentrated at the periphery of the central vein (CV) most of the bifurcated portal branches were observed including portal vein (PV), hepatic artery (HA) and bile duct (BD) were perfectly located. Normal features of hepatocytes, kuffer's cells, sinusoids, were well maintained. Similarly, Anderson and Borlak, (2006) ${ }^{40}$ reported normal histological features of hepatic cells, showing above type of normal architecture indicating routine function and also in control group. Similarly, the intestinal section in control rat showed normal histological architecture. Normal histological structure of the intestinal villi is were observed in the sectional view. Intestinal lumen were appeared normal. Morphologically sectional view showed well differentiation among intestinal layers from mucosal - (absorptive cells /micro villi) folding to external cells. Overall the morphometric arrangement of both intestine and gland were normal and performing active biological role in complete digestion and absorption mechanism. Overall, we found control rats were normal and does not showing any stressful behavioural changes during experimental procedure. (Plate No. 2 Figure a and e).

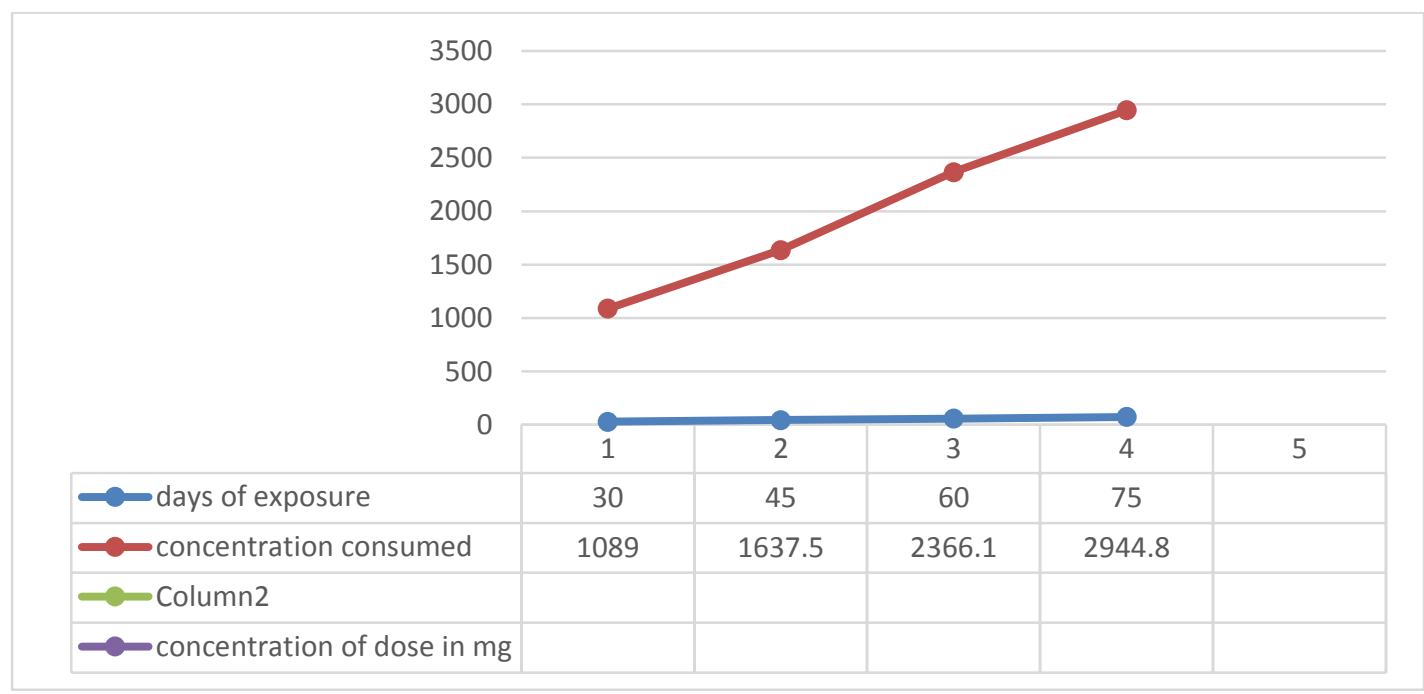

Graph 2: Benzoic acid (dose in mg) consumed by Rattus norvegicus during entire period of induction in days.

\section{Pathology of the liver and intestine:}

In the present investigation, sections were assessed for pathological alterations induced due to dose dependent cytotoxicity in both liver and intestinal tissue. Huang, et. al., $(2007)^{41}$ documented experimental study on hepatotoxicity of topiramate in young rats and showed prominent pathological changes in the hepatocytes. Aydin et. al., (2003) ${ }^{42}$ observed major histopathology changes in liver and renal tissues which were induced by Ochratoxin -A and melatonin in rats. Copple et. al., (2002) ${ }^{43}$ under pathological investigation reported endothelial 
cell injury and fibrin deposition in rat liver after induced monocrotaline exposure. Chipchase et. al., (2003) $)^{44}$ observed cytoarchitecture of hepatic cells with the different biological functions and also focused on characterization of premature liver polyploidy in DNA repair (Ercc1)deficient mice.

Cullen, (2005) $)^{45}$ explained different types of mechanistic classification of hepatocytes injury and its biomechanics against different organic and inorganic toxic compounds with their rate of bioaccumulations. Kluge et. al., (2006) ${ }^{46}$ observed effect of benzoic acid on nutrient digestibility and dependent growth performance piglets. But, excess concentration of benzoic acid can create free radicals and damage cells. Guingand et. al., (2005) ${ }^{47}$ studied biological influence of adding 0.5 or $1 \%$ on benzoic acid resulting to increased content of nitrogenous material showing acidified cytoplasmic content of vital cells.

Likewise in our induced toxicity we found cellular changes by their shape and size pertaining to differentiations in the exposure period. HE stained sections of liver after initial phase of intoxication showed mild or unnoticed changes in the shape and size of hepatic tissue. After 45 days exposure period hepatic cells became hypertrophic, compared to normal size of total liver was found increased, (fig. b). Hhypertrophic hepatic cells has changed their nuclei cytoplasmic ratio. Polygonal nature of hepatic cells were noticeably changed and found somewhat rounded or irregular. Luminal space was widened, sinusoids were found irregular, some cells were damaged and cellular debris was seen in the internal liminal space indicating heavy pathological signs. Severe congestion of circulatory linings with dilated sinusoids were observed. Major disorganization indicated that, liver cells were injured and caused deterioration of nearby hepatic lobules after 60 days and upto 75 days of exposure against induced dose of benzoic acid. After 75 days, hepatic cells were prominently enlarged, sinusoidal dilations and along with above alterations, some of them were became necrotic releasing cellular debris in interstitial space which remarkably noticed under microscope. Tissue sections showed major vacuolization/microsteatosis and fragmented nuclei/ loss of nuclear membrane, indicating severe inflammation of hepatocytes, which has reflected to the functional limitations in animals. Joana Barbosa et. al., $(2020)^{48}$ reported similar pathological observations as centrilobular congestion, cytolysis and sinusoidal dilatation in repeated administration of clinical doses of Tramadol and Tapentadol in Wistar rats. (Fig. c and d).

Benzoic acid induced groups, were histological tissue sections of intestine stained with HE indicated severe degenerative changes. 45 days after induced toxicity morphological structure of the ileum was slightly changed. Hypertrophy and cellular congestion were more prominent in the mucosal lining of intestine. Sectional view after 60 and 75 days of exposure showed grossly abnormal epithelial cells lined to the luminal side of the ileum. Mucosal cells were detached and due to ruptured cells, does not showed continuous lining around liminal part of 
the ilium. After 75 days of exposure, Sectional view revealed major destruction of mucosal folding's found in the form of villus. Morphologically shape and surface of the villus was damaged reflecting problem in the complete digestion and absorption. This may be the internal reason animal has became more restless and aggressive among them. Similarly, Carr et. al., $(1992 a)^{49}$ documented morphological and cytometric changes in villous shape and mural structure in neutron irradiated small intestine. Papadomichelakis et. al., $(2011)^{50}$ documented severe influence of dietary benzoic acid mixture on rate of metabolic digestion and absorption of experimental animal model rabbits. Guzman and Solter, (2002) ${ }^{51}$ while investigation documented characterization of sub lethal microcystin-LR exposure in mice and observed cellular alterations causing to lethal effects in experimental mice. Stephane et. al., (2019) ${ }^{52}$ reported number of histopathological and metabolic changes in rats were exposed to administration of CDK4/6 Inhibitors. Biochemically when any of chemical in excessive concentration entered into liver, it can interfere the rate of metabolism and cause toxic impact. Wang et. al., (2006) ${ }^{53}$ also reported radiation induced pathological responses in rat small intestine by capsaicin-sensitive nerves. Brennan et. al., (1998) ${ }^{54}$ observed similar kind of acute pathological alterations on small intestinal morphological parameters against increasing dose of chemicals. Weichselbaum and Klein, $(2018)^{55}$, experimentally supplemented intestinal epithelial response against toxicological chemicals to induce morphological damage leading to stress among experimental animals.

Scientist reported that, doses dependent administration of Mono Sodium Glutamate against rodents were assessed for study of morphological and biochemical alterations in experimental animals (Eweka et al., 2011 and Bhivate et. al., 2019) ${ }^{55,56}$. Where if, abuse of MSG can bioaccumulate in the biological tissue and cause morphological disturbances, sometime tissue injury like hypertrophy, necrosis and cellular debris may be found, (Marisa et. al., 2014). Bhivate et. al., (2018) ${ }^{58,59}$ documented haematological alterations related to their size and shape of corpuscular cells due to stepwise induced dose of monosodium glutamate in experimental animal Mus musculus. Chatman et. al., (2009) ${ }^{60}$ provided number of new strategy for risk management of drug-induced phospholipidosis in the experimental model as detoxification mechanism. Geller et. al., (2008) ${ }^{61}$ critically documented several applications of immunohistochemistry in the liver and gastrointestinal neoplasms, where they concluded several biological changes in the biomolecules of hepatic cells causing metabolic deficiency leading to behavioural changes among experimental animals.

\section{CONCLUSION:}

Modular Education Programme in Toxicological Pathology published toxicological report that, vital organ like hepatocytes were found damaged because of induced drug administration and 
can leads to physiological abnormality (BSTP, 2007) ${ }^{62}$. Brooks and Roe, $(1985)^{63}$ reported pathophysiology of digestive system regarding hepatocellular adenoma in liver of rat and noted severe metabolic alterations on the body energetics. Supplementary biochemical components in food can change the food quality, but at the same time it may interfere the rate of biochemical reactions in the body. Its abuse can be harmful. In the study, the pathological observations showed that, After 60 days of exposure to Benzoic acid showed that the polyhedral arrangement in radial rows of hepatic cells altered. Bannasch, (2003) $)^{64}$ commented cystic degeneration/spongiosis hepatis against induced pathology and similarly noted biological disturbances in the hepatic cells. Aktac, et. al., (2002) ${ }^{65}$ also reported that the effect of benzoic acid as an antimicrobial agent cause biochemical and histopathological disturbances in against mouse hepatocytes. We also found cecellular disorientation of liver and intestinal cells indicating pathophysiology of interested organs. Induced dose of benzoic acid with respect to exposure period has made prominent pathological symptoms as result animals showed stressful behaviour in the rearing cages, they became more aggressive. Internal pathology has depleted the weight and biomechanics of experimental animals. All the above pathological observations strengthen efficacy for dose dependent toxic capabilities of benzoic acid against Rattus norvegicus. Further work in this direction is in pipe line for final conclusion regarding toxicological investigations.

\section{Compliance with ethical standards}

\section{ACKNOWLEDGMENTS:}

We are thankful to the Head of Department of Zoology, Shivaji University, Kolhapur for providing facility to carry out present work.

\section{DISCLOSURE OF CONFLICT OF INTEREST:}

The authors declare that they have no conflicts of interest.

\section{Statement of ethical approval:}

Investigation was carried out with permission of authorized CPCSEA approval for animal experiment. Department of Zoology, Shivaji University, Kolhapur (1825/PO/EReBi/S/15/CPCSEA).

\section{PLATE NO.1}




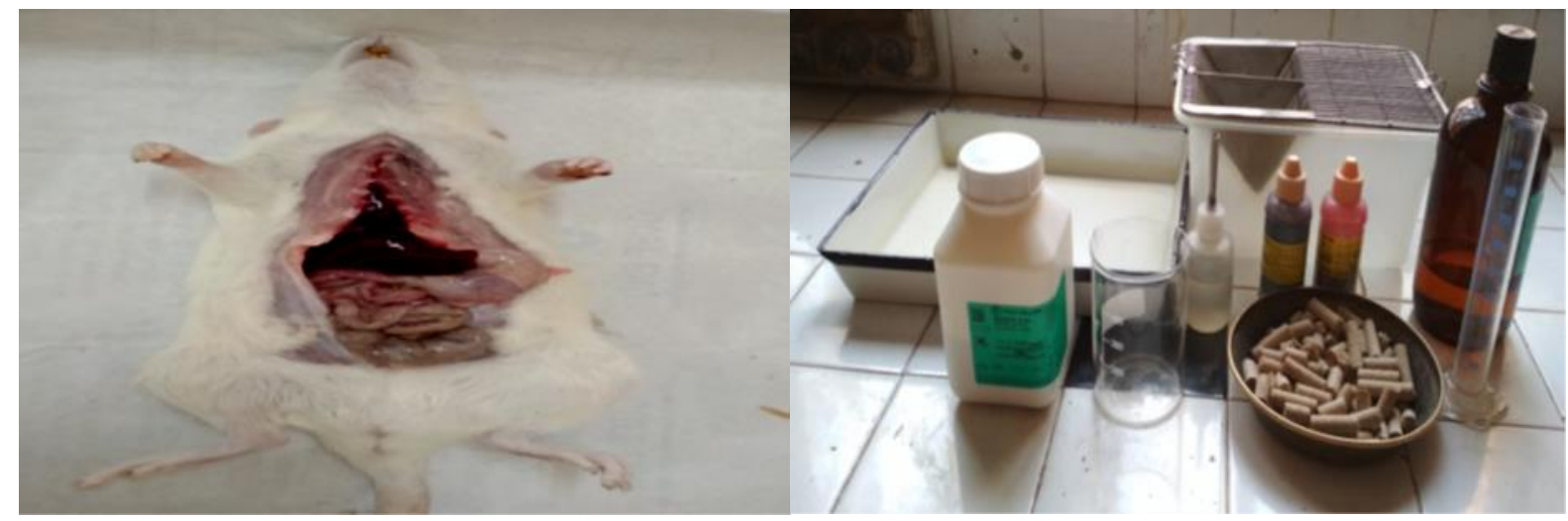

\section{Figure A}

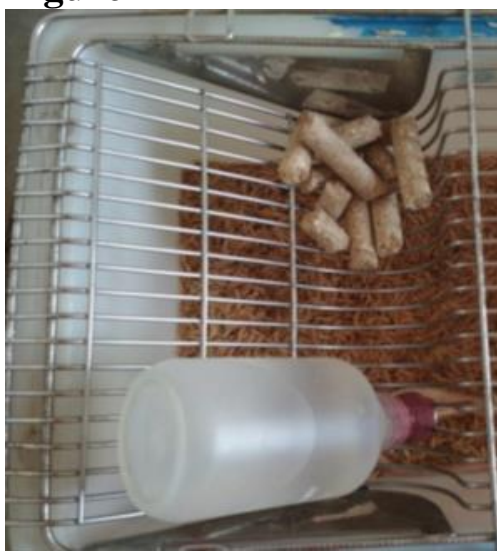

Figure C

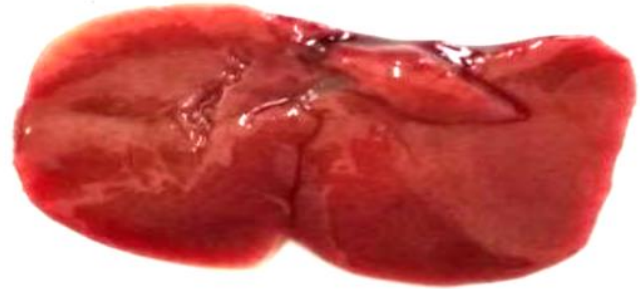

Figure E
Figure B

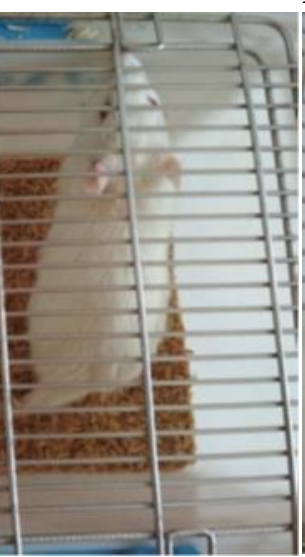

Figure D

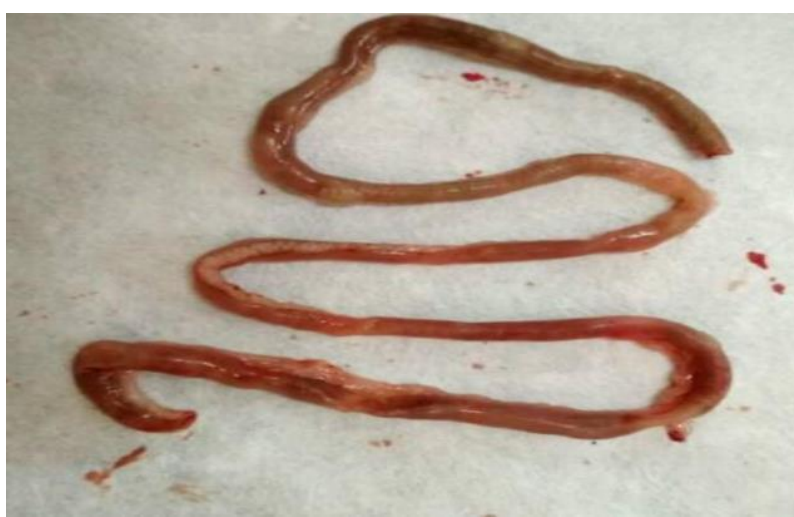

Figure F

Plate No. 1 Figure. A- Visceral mass of experimental animal Wistar rats (Rattus norvegicus) showing digestive tract anatomy. Fig. B- laboratory equipments and benzoic acid powder in bottle, Fig. C- Experimental animal in control group- normal behevior Fig. D- Experimental animal from benzoic acid intoxicated animal after 75 days showing lithargic or aggressive mobility Fig. E- Gross appearance for a normal rat liver and Fig. F- Segmental region of small intestinal part of rat.

PLATE NO. 2 


\section{PLATE NO. 2}

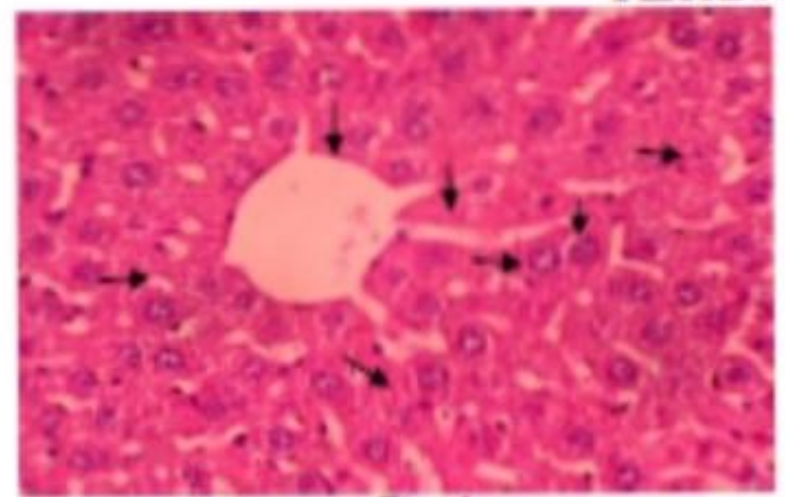

Fiz. A

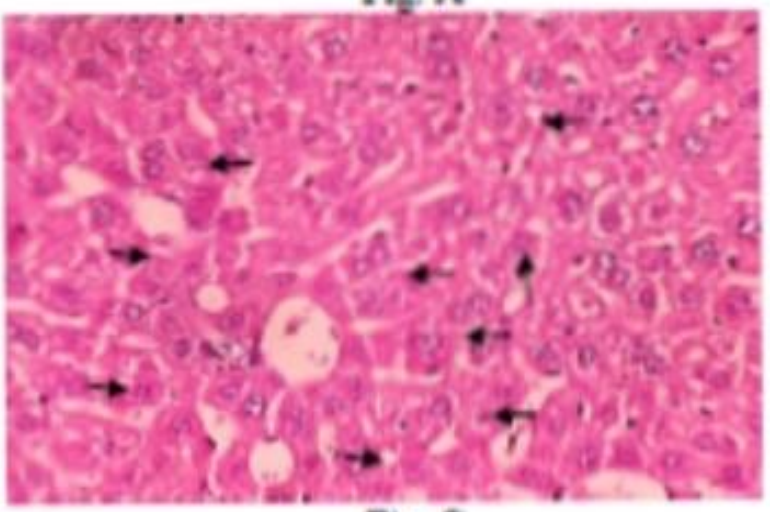

Fig. C

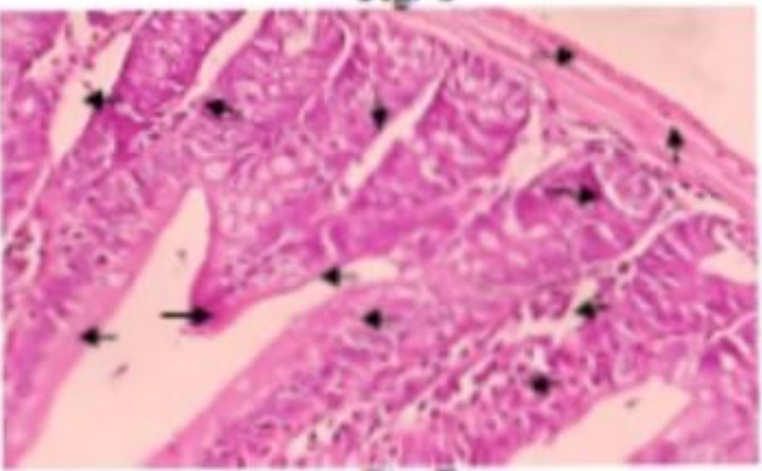

Fiz. E

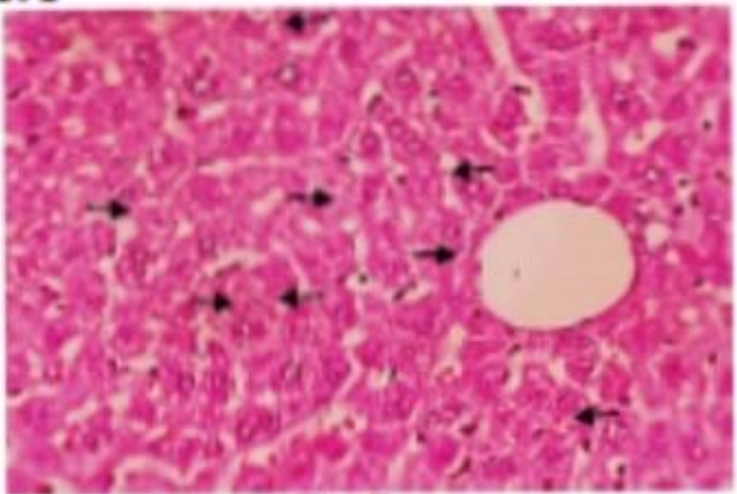

Fig. B

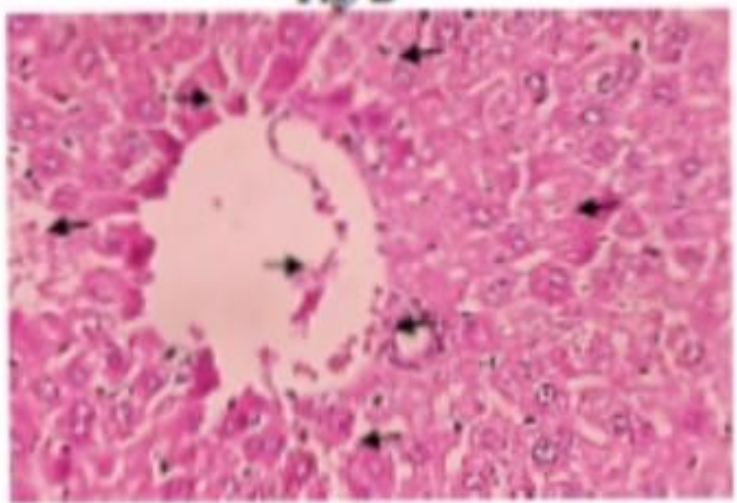

\section{Fig. D}

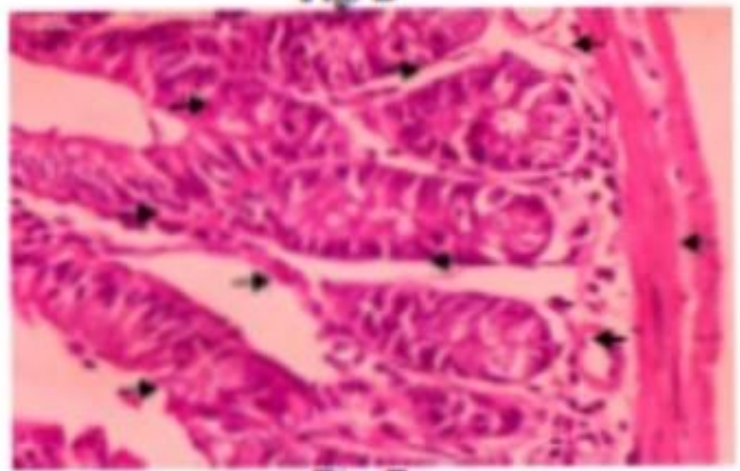

Fig $\mathrm{F}$

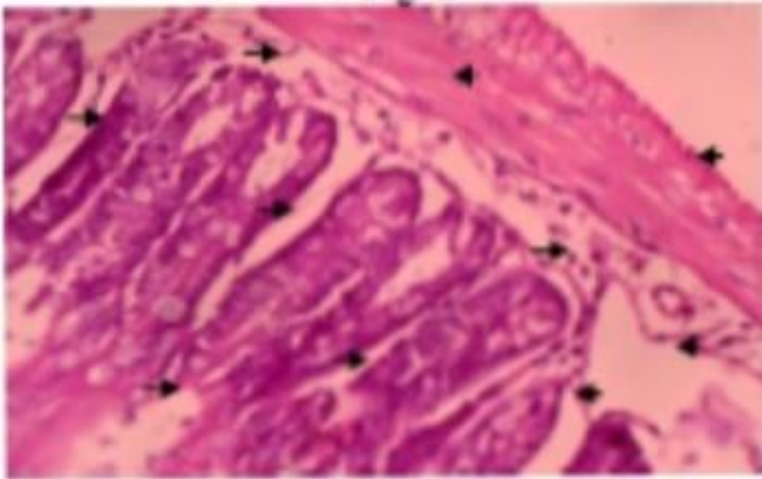

Fit. G

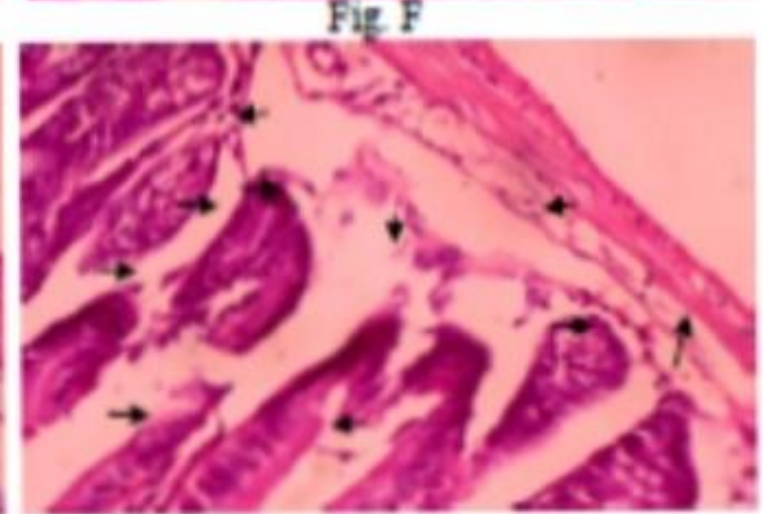

Fig $\mathrm{H}$

Plate No. 2 Fig. A- Liver of control, untreated rat section shows normal architecture of hepatic strands, with hepatocytes in wistar rats- Rattus norvegicus, (H-E stain X 400). Fig. BHepatocytic globules showing histopathological alterations after 45 days of Benzoic acid induction. (H-E stain X 400). Fig. C and Fig. D- Hypertrophied hepatocytes with congestion and deeply stained shrunken nuclei and hepatic necrosis with hemorrhagic area and disturbed 
architecture of hepatic tissue (H-E stain X 400). Fig. E- Hostology of Intestine from control rat showing normal cellular pattern. (H-E stain X 400). Fig. F- Intestine of rat intoxicated with Benzoic acid after 45 days showing hyperplasia and hyper activity of mucoid cells. (H-E stain $X$ 400). Fig. $G$ and Fig. H- Histological alterations in the intestine after 60 and 75 days showing degenerative changes in the mucoidal cells with cellular debris and small hemorrhagic

\section{REFERENCES:}

1. IPCS, (1993) International Chemical Safety Card - Benzoic acid. Geneva, World Health Organization, International Programme on Chemical Safety (ICSC 0103).

2. WHO, (1999) Safety evaluation of certain food additives. Prepared by the 51st meeting of the Joint FAO/WHO Expert Committee on Food Additives (JECFA). Geneva, World Health Organization, pp. 403-414 (WHO Food Additives Series 42).

3. WHO, (1996) Toxicological evaluation of certain food additives. Prepared by 46th meeting of the Joint FAO/WHO Expert Committee on Food Additives (JECFA). GENEVA, World Health Organization (WHO Food Additives Series 37).

4. BMA (British Medical Association) (1998) Antifungal preparations - Benzoic acid. Wallingford, Pharmaceutical Press (British National Formulary 507).

5. Kristie Leong, M. D. (2009) Sodium Benzoate: An Unhealthy Food Preservative? Int. J. Toxicol. $3: 23-50$.

6. Center for Drug Evaluation and Research. (2017), Kisqali Scientific Basis for Approval. Silver Springs, MD: U.S. Food and Drug Administration; 2017. https://www.accessdata.fda.gov/drugsatfda_docs/nda/ 2017/209092Orig1s000MultidisciplineR.pdf

7. U.S. Food and Drug Administration, (2018); Verzenio Label. Silver Springs, MD: U.S. Food and Drug Administration; 2018. https://www.accessdata.fda. gov/drugsatfda_docs/label/2018/208855s000lbl.pdf.

8. del Olmo, J. Calzada, and M. Nũnez, ( 2015), "Benzoic acid and its derivatives as naturally occurring compounds in foods and as additives: Uses, exposure, and controversy," Critical Reviews in Food Science and Nutrition, vol. 57, no. 14, pp. 3084-3103.

9. Mroz Z.; Jongbloed, AW; Partanen, KH; Vreman, K; Kemme PA.; Kogut J., (2000); The effects of calcium benzoate in diets with or without organic acids on dietary buffering capacity, apparent digestibility, retention of nutrients and manure characteristics in swine. Journal of Animal Science 78, 2622-2632. 
10. Srour R (1989) Benzoic acid. In: Srour R, ed. Aromatic intermediates and derivatives. Paris, pp. A.IV.1-A.IV.14 (unpublished report) [cited in BUA, 1995].

11. Chr. Plitzner, K. Schedle, V. Wagner, T. Ettle, W. Windisch ( 2006), Influence of adding 0.5 or $1.0 \%$ of benzoic acid on growth performance and urinary parameters of fattening pigs, Slovak J. Anim. Sci., 39, (1-2): 69 - 73.

12. D. Cong, A. K. Y. Fong, R. Lee, and K. S. Pang, (2001); “Absorption of benzoic acid in segmental regions of the vascularly perfused rat small intestine preparation," Drug Metabolism and Disposition, vol. 29, no. 12, pp. 1539-1547, 2001.

13. Birch RR, Biver C, Campagna R, Gledhill WE, Pagga U, Steber J, Reust H, Bontinck WJ (1989); Screening of chemicals for anaerobic biodegradability. Chemosphere, 19(10-11):1527-1550.

14. Bindslev-Jensen C.,(1998); ABC of allergies. Food allergy. British medical journal, 316:1299-1302.

15. Nair, B., (2001). Final report on the safety assessment of benzyl alcohol, benzoic acid and sodium benzoate. Int. J. Toxicol. $3: 25-50$.

16. RCC Notox, (1988b) Eye irritation/corrosion study of benzoic acid in the rabbit. DD'sHertogenbosch, RCC Notox B.V. (unpublished report).

17. Monsanto Co., (1983) Primary eye irritation of benzoic acid to rabbits. St. Louis, MO, Monsanto Company, Environmental Health Laboratory.

18. Mroz, Z.; Jongbloed, A. W.; Partanen, K. H.; Vreman, K.; Kemme, P. A.; Kogut, J., (2000); The effects of calcium benzoate in diets with or without organic acids on dietary buffering capacity, apparent digestibility, retention of nutrients and manure characteristics in swine. Journal of Animal Science 78, 2622-2632.

19. Kristie Leong, M. D. (2009), Sodium Benzoate: An Unhealthy food preservative? Int. J.Tosicol.3: 23-50.

20. Abd-AiGadir, M. I., Ihaimer, M. M., Sabah Elkheir, M. K. and Idris, O. F. (2009). Effect of benzoic acid and combination of benzoic with citric acid as food additives on the renal function of experimental rats. Asian J. Clin. Nutri. 1 (2) : 83-87.

21. Bhelonde, J. J. and Ghosh, R. C. (2004) Effect of subchronic fenpropathrin toxicity on feed consumption and body weight gain in rats. Indian Vet. J. 81 : 644-646.

22. Priya, R. J., Sridhar, R., Balchandram, C. and Murali Manohar, B. (2008); Evolution of toxic effect of food preservative sodium benzoate in rats.

23. Hirose M, Yasui T, Okada A, Hamamoto S, Shimizu H, Itoh Y, Tozawa K and Kohri K., (2010); Renal tubular epithelial cell injury and oxidative stress induce calcium oxalate crystal formation in mouse kidney. International journal of urology, 17(1), 8392. 
24. Kubota K, Ishizaki T, (1991) Dose-dependent pharmacokinetics of benzoic acid following oral administration of sodium benzoate to humans. European journal of clinical pharmacology,41(4):363-368.

25. D. Zhu, Y. Ma, S. Ding, H. Jiang, and J. Fang, (2018) "Effects of melatonin on intestinal micro biota and oxidative stress in colitis mice," Bio Med Research International, Article ID 2607679.

26. L. Weichselbaum and O. D. Klein, (2018); “The intestinal epithelial response to damage," Science China Life Sciences, vol. 61, no. 10, pp. 1205-1211.

27. Cakıroglu B, Eyyupo glu E, Hazar AI, Uyanik BS and Nuho־glu B. (2016) Metabolic assessment of recurrent and Irst renal calcium oxalate stone formers. Archivio Italiano diUrologia e Andrologia, 88,101-105.

28. H. Diao, ( 2013) Effects of Benzoic Acid and ymol on Growth Performance and Gut Health in Piglets, Sichuan Agricultural University.

29. Polonen, I.; Toivonen, V.; Makela , J., (1998); Different combinations of formic, propionic and benzoic acids in slaugther offal preservation for feeding to fur animals. Animal Feed Science and Technology 71, 197-202.

30. Drury, R.A.B. and Wallington, E.A. (1980), In Carleton's Histological technique. 4th ed. Oxford Univ. Press, New York, Toronto.

31. Windisch, W. M.; Gotterbarm, G. G.; Roth, F. X., (2001); Effect of potassium diformate in combination with different amounts and sources of excessive dietary copper on production performance in weaning piglets. Archives of Animal Nutrition 54, 87-100.

32. F. A. Andersen,( 2001), "Final report on the safety assessment of Benzyl Alcohol, Benzoic Acid, and Sodium Benzoate," International Journal of Toxicology, vol. 20, no. 3, pp. 23-50, 2001.

33. K. Verhoeckx, P. Cotter, I. L’opez-Exp'osito et al.,( 2015) e Impact of Food Bioactives on Health, Springer International Publishing.

34. Wibbertmann, A. J. Kielhorn, J. Koennecker, G.. Mangelsdorf I, Melber, Fraunhofer, C. (2005) BENZOIC ACID AND SODIUM BENZOATE Institute for Toxicology and Aerosol Research, Hanover, Germany World Health Organization Geneva, 2000, WHO Library Cataloguing-in-Publication Data, Concise international chemical assessment document ; 26, NLM Classification: QD 341.A2

35. Gad, S. C., and Rousseaux, C. G. (2002), Use and misuse of statistics as an aid in study interpretation. In Handbook of Toxicologic Pathology (W. M. Haschek, C. G. Rousseaux, and M. A. Wallig, eds.), Vol. 1, pp. 327-418. Academic Press, San Diego, California. 
36. J. R. Turner, (2009); “Intestinal mucosal barrier function in health and disease, "Nature Reviews Immunology, vol. 9, no. 11, pp. 799-809.

37. Graham, M. J., and Lake, B. G. (2008), Induction of drug metabolism: Species differences and toxicological relevance. Toxicology 254, 184-91.

38. Goodman, Z. D., and Ishak, K. G. (2006), Hepatobiliary system and pancreas. In Surgical Pathology and Cytopathology (S. G. Silverberg, ed.), Vol. 2, 4th ed., pp. 1465526. Elsevier, Oxford, UK.

39. Hailey, J. R., Walker, N. J., Sells, D. M., Brix, A. E., Jokinen, M. P., and Nyska, A. (2005), Classification of proliferative Hepatocellular lesions in Harlan Sprague-Dawley rats chronically exposed to dioxin-like compounds. Toxicol Pathol 33, 165-74.

40. Anderson, N., and Borlak, J. (2006), Drug-induced phospholipidosis. FEBS Lett 580, $5533-540$.

41. Huang, J., Ren, R. N., Chen, X. M., and Ye, L. Y. (2007). An experimental study on epatotoxicity of topiramate in young rats. Zhongguo Dang Dai Er Ke Za Zhi 9, 54-8.

42. Aydin, G., Ozcelik, N., Cicek, E., and Soyoz, M. (2003), Histopathological changes in liver and renal tissues induced by Ochratoxin A and melatonin in rats. Hum Exp Toxicol 22, 383-91.

43. Copple, B. L., Banes, A., Ganey, P. E., and Roth, R. A. (2002), Endothelial cell injury and fibrin deposition in rat liver after monocrotaline exposure. Toxicol Sci 65, 309-18.

44. Chipchase, M. D., O’Neill, M., \& Melton, D. W. (2003), Liver biology and pathobiology - Characterization of premature liver polyploidy in DNA repair (Ercc1)deficient mice. Hepatology. Official Journal of the American Association for the Study of Liver Diseases 38, 958-66.

45. Cullen, J. M. (2005), Mechanistic classification of liver injury. Toxicol Pathol 33, 6-8.

46. H. Kluge, J. Broz, and K. Eder,( 2006), "Effect of benzoic acid on growth performance, nutrient digestibility, nitrogen balance, gastrointestinal microflora and parameters of microbial metabolism in piglets," Journal of Animal Physiology and Animal Nutrition, vol. 90 , no. 7-8, pp. 316-324.

47. Guingand, N. - Demerson, L. - Broz, J. (2005), Influence of adding 0.5 or $1 \%$ on benzoic acid to the feed of growing-finishing pigs on ammonia emission and performance. Vol. 1, ISAH 2005 - Warsaw, Poland.

48. Joana Barbosa, Juliana Faria, Fernanda Garcez, Sandra Leal, Luís Pedro Afonso, Ana Vanessa Nascimento, Roxana Moreira, Odília Queirós, Félix Carvalho, Ricardo Jorge Dinis-Oliveira. ( 2020); Repeated Administration of Clinical Doses of Tramadol and Tapentadol Causes Hepato- and Nephrotoxic Effects in Wistar Rats, Pharmaceuticals , 13, 149; doi:10.3390/ph13070149 www.mdpi.com/journal/pharmaceuticals. 
49. Carr KE, McCullough JS, Nelson AC, Hume SP, Nunn S, Kamel HM, (1992a), Relationship between villous shape and mural structure in neutron irradiated small intestine. Scanning Microsc 6:561- 572.

50. G. Papadomichelakis, K. C. Mountzouris, E. Zoidis, and K . Fegeros,( 2011), "Influence of dietary benzoic acid addition on nutrient digestibility and selected biochemical parameters in fattening rabbits," Animal Feed Science and Technology, vol. 163 , no. $2-4$, pp. 207-213.

51. Guzman, R. E., and Solter, P. F. (2002), Characterization of sublethal microcystin-LR exposure in mice. Vet Pathol 39, 17-26.

52. Stephane Thibault1, Wenyue Hu1, Brad Hirakawa1, Dalia Kalabat1, Tania Franks2 , Tae Sung1, Su Khoh-Reiter1, Shuyan Lu1, Martin Finkelstein3, Bart Jessen1, and Aida Sacaan1,( 2019) American Association for Cancer Research.), Intestinal Toxicity in Rats Following Administration of CDK4/6 Inhibitors Is Independent of Primary Pharmacology, Molecular Cancer Therapeutics, Published Online First November 6, 2018; DOI: 10.1158/1535-7163.MCT-18-0734. Molecular Cancer Therapeutics Online (http://mct.aacrjournals.org/).

53. Wang J, Zheng H, Kulkarni A, Ou X, Hauer-Jensen M, (2006), Regulation of early and delayed radiation responses in rat small intestine by capsaicin-sensitive nerves. Int $\mathbf{J}$ Radiat Biol Phys 1 64(5):1528-1536.

54. Brennan PC, Carr KE, Seed T, McCullough JS, (1998); Acute and protracted radiation eVects on small intestinal morphological parameters. Int J Radiat Biol 73:691-698.

55. L. Weichselbaum and O. D. Klein,( 218), “The intestinal epithelial response to damage," Science China Life Sciences, vol. 61, no. 10, pp. 1205-1211, 2018.

56. Eweka, A. O., Igbigbi, P. S. \& Ucheya, R. E. (2011). "Histochemical Studies of the Effects of Monosodium Glutamate on the Liver of Adult Wistar Rats," Annal of Medical \& Health Sciences Research, 1(1), 21-9.

57. Bhivate S. B. and Kamble N. A. (2019), Cytotoxic effect of Monosodium Glutamate against liver, kidney and haematological parameters of male mice Mus musculus International Journal of Research and Analytical Reviews (IJRAR) 2019 IJRAR June 2019, Volume 6, Issue 2 www.ijrar.org

58. Marisa Rangel, Joyce C. G. Martins1, Angélica Nunes Garcia, Geanne A. A. Conserva , Adriana Costa- Neves , CéliaLeiteSant'Anna and Luciana Retz de Carvalho (2014), "Analysis of the Toxicity and Histopathology Induced by the Oral Administration of Pseudanabaenagaleata and Geitlerinemasplendidum (Cyanobacteria) Extracts to Mice". 12(1): 508-524. 
59. Bhivate S. B. and Kamble N. A. (2018). "Haematological alterations against chronic exposure of Monosodium glutamate (MSG) on male mice Musmusculus." Arhat international journal special edition.

60. Chatman, L. A., Morton, D., Johnson, T. O., and Anway, S. D. (2009). A strategy for risk management of drug-induced phospholipidosis. Toxicol Pathol 37, 997-1005.

61. Geller, S. A., Dahll, D., and Alsabeh, R. (2008). Application of immunohistochemistry to liver and gastrointestinal neoplasms: Lysosomal alterations in heart and liver of mice treated with doxorubicin. Arch Pathol Lab Med 132, 490-99.

62. BSTP. (2007), Modular Education Programme in Toxicological Pathology. Module 8: Liver. Cambridge University, Department of Pathology, Cambridge, UK.

63. Brooks, P. N., and Roe, F. J. C. (1985), Hepatocellular adenoma, liver, rat. In Monographs on Pathology of Laboratory Animals. Digestive System (T. C. Jones, U. Mohr, and R. D. Hunt, eds.), pp. 47-52. Springer, New York.

64. Bannasch, P. (2003). Comments on R. Karbe and R. L. Kerlin (2002), Cystic degeneration/spongiosis hepatis (Toxicol Pathol 30, 216-227). Toxicol Pathol 5, 56670.

65. Aktac, T.,Kaboglu,A.,Ertan,F.,Ekinci, F. and Huseyinova, G. (2002), The effect of citric acid (antioxidant) and benzoic acid (antimicrobial agent) on the mouse liver: Biochemical and histopathological study.

\section{BJMHR is \\ - Peer reviewed \\ - Monthly \\ - Rapid publication \\ - Submit your next manuscript at editor@bjmhr.com

